\title{
NURSES' PERCEPTIONS OF SPIRITUALITY AND SPIRITUAL CARE AND THE CHALLENGES OF LEARNING SPIRITUALITY
}

\author{
Wastu Adi Mulyono1, Chung-Hey Chen²
}

1. Lecture, Jurusan Keperawatan FIKES, Universitas Jenderal Soedirman Purwokerto, Jawa Tengah, Indonesia.

2. Professor, Department of Nursing, National Cheng Kung University, Taiwan, ROC.

\begin{abstract}
Background. Nurses face barriers both from the environment and from themselves in providing spiritual care. Their perception to the spirituality as well as the spiritual care may contribute into this situation. Aim. This study was to identify the Indonesian nurse's perception of spirituality and spiritual care. Methods. A cross-sectional survey investigated 273 nurses in Central Java, Indonesia recruited through a convenience sampling. The Spirituality Spiritual Care Rating Scale (SSCRS) Bahasa Indonesia version was applied to measure the nurses' perceptions. Six other questions related to nurses' prior knowledge, responsibilities and work experiences were added. To examine the differences in the nurse's perception of Spirituality (SP) and Spiritual Care (SC), independent t-test and One-Way ANOVA were applied. Findings. Obtained score means were Spirituality 20.0 (2.0), Spiritual Care 46.2 (4.3), and total SSCRS 66.1 (4.5). There was the significant different perception of spirituality and spiritual care as a total, and in subscale of spirituality based on the geographic location $(p=0.006)$. Respondents felt well informed $(52.2 \%)$, got training $(4.8 \%)$, capable of delivering spiritual care $(70 \%)$, mostly considered the patient spiritual need through listening and observing patients by themselves (67.9\%). Conclusion. Nurse perception of spirituality and spiritual care were not different based on respondent characteristics, except the respondents' work geographical area. Challenges in teaching spirituality were confirmed. This study provided basic information in describing Indonesian nurses' perception on spirituality and spiritual care.
\end{abstract}

Keywords: spirituality, spiritual care, nursing education, administration

\begin{abstract}
ABSTRAK
Latar Belakang. Para perawat menghadapi hambatan dalam memberikan asuhan spiritual baik dari lingkungan maupun mereka sendiri. Persepsi mereka terhadap spiritualitas dan asuhan spiritual kemungkinan berkontribusi terhadap permasalah ini. Tujuan. Penelitian ini untuk mengidentifikasi persepsi perawat terhadap spiritualitas dan asuhan spiritual. Metode. Penelitian survei cross-sectional sudah dilakukan untuk meneliti 273 perawat di Jawa Tengah, Indonesia yang diperoleh melalui teknik convenience sampling. Spirituality Spiritual Care Rating Scale (SSCRS) versi Bahasa Indonesia diimplementasikan untuk mengukur persepsi para perawat. Enam pertanyaaan lain berkaitan dengan pengetahuan sebelumnya, tanggung jawab, dan pengalaman kerja perawat ditambahkan. Untuk menguji perbedaan persepsi spiritualitas (SP) dan Asuhan Spiritual (SC), independent t-test dan OneWay ANOVA diaplikasikan. Temuan. Rerata skor Spiritualitas 20,0 $( \pm 2,0)$, Asuhan Spiritual 46,2 $( \pm 4,3)$, dan SSCRS total $66,1( \pm 4,5)$. Terdapat perbedaan yang bermakna pada persepsi spiritual dan asuhan spiritual baik secara total maupun sub-kategoriny berdasarkan variasi lokasi geografis perawat $(p=0,006)$. Para responden menyatakan sudah terinformasi konsep spiritualitas dan asuhan spiritual dengan baik $52,2 \%$, memperoleh pelatihan $4,8 \%$, merasa mampu memberikan asuhan spiritual $70 \%$, dan mereka menyadari bahwa pasien memiliki kebutuhan spiritual setelah mendengarkan dan mengamati sendiri keluhan dari pasiennya 67,9\%. Simpulan. Tidak ada variasi persepsi perawat terhadap spiritualitas dan asuhan spiritual menurut karakteristik demografik, kecuali lokasi geografis. Selain itu, tantangan dalam mengajarkan konsep spiritualitas juga terkonfirmasi oleh temuan penelitian ini. Penelitian ini telah memberikan inforasi mendasar yang menggambarkan persepsi perawat Indonesia terhadap spiritualitas dan asuhan spiritual.
\end{abstract}

Kata kunci: spiritualitas, asuhan spiritual, pendidikan keperawatan, administrasi 


\section{BACKGROUND}

Addressing patient spirituality in the clinical setting is in challenging situation nowadays. Even though spirituality is an important need for patient, as well as the physical need; many patients complained lack of support to meet the spiritual need (Balboni et al., 2010). Nurse faced barriers in proving spiritual care in the clinical setting. Unsupportive environments, lack of the nursing guidelines, nurses' lack of time, and lack of training and education of the issue (Rushton, 2014; Stranahan, 2001) were responsible for lacking spiritual care in clinical setting. Moreover, nurses felt unconfident in separating personal belief and professional practice (McSherry \& Jamieson, 2013).

This feeling comes from an inadequate knowledge or misperceives spiritual care as other profession responsibility might cause nurse reluctant to meet it (Ruder, 2013). Because nurse's educational level, the length of work experience and department of employment were determinants on the nurse's perceptions of spirituality and spiritual care (Ozbasaran, Ergul, Temel, Aslan, \& Coban, 2011). The negative perception of providing spiritual care in clinical practice originate from low exposure to the spirituality concept in the prior nursing education.

In the nursing education, barriers of teaching spirituality came from teachers, students, and environment (Baldacchino, 2011). Student and teacher experienced discomforting with the spiritual issue during teaching learning process in the school (Boswell, Cannon, \& Miller, 2013). Besides that, the abstractness of concept generated a demand for a clear guidance and definition from the nursing profession. Likewise, consistent approaches to teaching the spirituality concept were important too (Timmins \& Neill, 2013). It shows that that the problem affects nearly every element of education systems.

On the other hand, Indonesian nursing education has been developing progressively recently. Bachelor level of nursing education growth significantly.
Nowadays 288 institutions registered as a member of Association of Indonesian Nurse Education ("Daftar Anggota AIPNI," 2016). Books, mass media and training use the term of spirituality or spiritual massively. In the nursing curriculum, the religion course takes two credits. As cultural belief may also nurturing the spirituality (Ozbasaran et al., 2011), it will develop nurse perception of spiritual care. However, there is no publication in Indonesia discussing spiritual care and the nurse perception of spirituality. This study is an initial step for further investigation in developing spiritual in educational and clinical settings. The purpose of this study is to identify Indonesian nurse's perception of spiritual care and spirituality and any influencing demographic characteristics of nursing practice.

\section{METHODS \\ Research Design}

A descriptive survey of nurses in Province Central lava, Indonesia, was undertaken using convenience sample to determine their perception of spirituality and spiritual care. Nurses who practiced in hospitals and community agency across the province were invited to participate.

\section{Population}

The sample of the study is nurses who work who worked as nurses in hospital, and community health. A convenience sampling was applied to recruit respondents. Nurses who already worked in the nursing service in the area of Province Central Java, Indonesia considered eligible as respondent. Those who have worked as administration staff only and have never been exposed into direct nursing care were excluded.

\section{Data Collection}

Data were collected during July to September 2015, in Province Central Java. Tree hundreds respondent invited to the study. Two experienced and trained research assistants distributed questioners to nurses in hospitals and public nursing services around Central Java. First, we identified the most accessible health facility to visit while delivering the 
questioner manually. After selecting the hospital, the research assistant contacted the person in hospital to help to distribute questioner. Then the research assistant visited the hospital in particular time after contacting the contact persons in the hospital to confirm the most comfortable time meet the nurses.

The research assistant then briefly explained the study purpose, a set of questioner was provided to fill. Respondents must sign the informed consent before filling the questioner. It took 30 minutes in average to complete the questioner before returning to the research assistant. If respondent had not finished the questioner, the questioner would be drawn back to the un-responded questioner.

\section{Instruments}

The Spirituality and Spiritual Care Rating Scale (SSCRS) (McSherry, Draper, \& Kendrick, 2002) was applied in the measurement. The instrument consists of 17 item, five items (a, b, g, k, and $n$ ) represent spiritual care, and 12 last items represent spirituality (McSherry \& Jamieson, 2011). An English expert from Jenderal Soedirman University translated the original SSCRS into Bahasa Indonesia. The translated SSCRS was reviewed by three faculties in the department of nursing who understand the spirituality concept to formulate the translated version scale through a consensus.

There was a small modification of wording in this Bahasa Indonesia version. The word church was translated into "tempat ibadah" instead of direct translation "gereja" that only represent Christian or "Masjid" that only represent Muslim term. Then, the word chaplain was also translated into "tokoh agama" instead of "pendeta or pastur" that only familiar for Christian or "ulama or imam" that particularly for Moslem. By changing these particular words into the most common term in Bahasa, we expected a wider application for the wider area in the future. The items tool were tested to 30 nurses who worked in Purwokerto (a town in Central Java). Cronbach Alpha on this study was 0.74 .

Beside SSCRS we added six questions to assess exposure of the spirituality concept, perception of responsibility, and experience in encounter spiritual need, exposure to the spirituality and spiritual care concept during previous nursing education and work, experiencing spiritual care, the capability after training

\section{Data analyses}

IBM SPSS Statistic Version 21 was utilized for data analyses. Firstly, univariate analyses described demographic characteristics, spiritual care and spirituality score, knowledge and experience. Following that, the association of spirituality and spiritual care were tested among various demographic characteristic. The independent t-test and One-Way ANOVA were implemented to compare the mean of SP, SC, and SSCRS between the characteristic of respondents. Ten respondents who are Catholic and Protestant were excluded from further analyses because we needed a cleaner information as Islam respondents dominated $96.5 \% \quad(n=273)$. We also conducted further analyses if the p-value is closely higher to 0.05 by adjusting the extreme value.

\section{RESULTS \\ Responds Rate}

From 300 distributed questioners, exactly 273 nurses responded the questioner. The responds rate reached 90 $\%$.

Table 1. Demographic Characteristic $(\mathrm{N}=273)$

\begin{tabular}{clcc}
\hline No & $\begin{array}{l}\text { Demographic } \\
\text { Characteristics }\end{array}$ & $\mathbf{n}$ & Percent \\
\hline 1 & Female & 160 & $58.6 \%$ \\
2 & Religion Islam & 273 & $100 \%$ \\
3 & Age & 99 & $36.3 \%$ \\
& $21-29$ & 129 & $47.3 \%$ \\
& $30-39$ & 41 & $15.0 \%$ \\
& $40-49$ & 4 & $1.5 \%$ \\
& $\geq 50$ & 192 & $70.3 \%$ \\
4 & Direct Care Provider & \\
5 & Geographic Location & 110 & $40.3 \%$ \\
& Southern & 77 & $28.2 \%$ \\
& Center & 86 & $31.5 \%$ \\
\hline & Northern & &
\end{tabular}


Jurnal Keperawatan Soedirman 14 (2) 2019 : 103 - 113

\begin{tabular}{|c|c|c|c|}
\hline No & $\begin{array}{l}\text { Demographic } \\
\text { Characteristics }\end{array}$ & $\mathbf{n}$ & Percent \\
\hline \multirow[t]{6}{*}{6} & Current work in area & & \\
\hline & Medical-Surgical & 138 & $50.5 \%$ \\
\hline & Maternity & 12 & $4.4 \%$ \\
\hline & Pediatric & 42 & $15.5 \%$ \\
\hline & $\begin{array}{l}\text { Emergency care and } \\
\text { Critical }\end{array}$ & 72 & $26.4 \%$ \\
\hline & $\begin{array}{l}\text { Community and } \\
\text { Mental Health }\end{array}$ & 9 & $3.3 \%$ \\
\hline \multirow[t]{6}{*}{7} & Work Experience & & \\
\hline & $<1$ years & 21 & $7.4 \%$ \\
\hline & $1-5$ years & 73 & $25.8 \%$ \\
\hline & $6-10$ years & 75 & $26.5 \%$ \\
\hline & $11-25$ years & 106 & $37.5 \%$ \\
\hline & $>25$ years & 8 & $2.8 \%$ \\
\hline 8 & Full Time & 247 & $90.5 \%$ \\
\hline 9 & Rotated Shift Nurse & 215 & $78.8 \%$ \\
\hline
\end{tabular}

Table 2. Results of SSCRS $(n=273)$

\begin{tabular}{lll}
\hline Scale & Mean (SD) & Range *) \\
\hline Spirituality & $20.0(2.0)$ & $5-25$ \\
Spiritual Care & $46.2(4.3)$ & $12-60$ \\
SSCRS & $66.1(4.5)$ & $17-85$ \\
\hline *) theoretical range score based on score \\
range
\end{tabular}

\section{Demographic Data}

Most respondents were $58.0 \%$ $(n=160)$ female (Table 1). Age ranged between 30-39 years old $47.3 \%(n=129)$. Respondents were direct care providers $70.3(n=192)$, work as fulltime employ $90.5 \%(n=247)$ as rotated nurses $78.8 \%$ $(n=215)$. Respondents reported over 11 years of nursing experience $(40.3 \%, n=1$ 14). The majority reported their practice in medical surgical specialties area $(50.5 \%$, $\mathrm{n}=138$ in Table 1).

The mean SP score and SC score were 20.0 (SD 2.0) and 46.2 (SD 4.3) respectively. In total score mean of SSCRS is 66.1 (SD 4.5). The score of Spiritual Care is more homogeny compare to spirituality and total SSCRS score (Table 2).

\section{Spiritual Care Education and Training}

We assessed the respondents' background knowledge with three questions (Table 4). First, we asked, "Selama menjalani pendidikan perawat, pernahkan mendapatkan mata kuliah yang mencakup perawatan spiritual? During the course of your nurse training, did you receive any lessons/lectures covering

Spiritual Care?" This question was to investigate the exposure of spirituality and spiritual care concept in the respondent previous nursing education. Most respondents agreed that they got exposed to spirituality or spiritual care concept 143 $(52.4 \%)$. The second question is "Sejak bekerja sebagai perawat, pernahkan Anda memperoleh training atau pelatikan yang mencakup perawatan spiritual? Jika ya, apakah Anda merasa mampu menjalankan perawatan spiritual/Since qualifying as a nurse, have you been on any training courses which covered spiritual care? If yes, after training, do you feel capable to deliver spiritual care?" This second question assessed the training during work as qualified nurses. Only $4.8 \%$ $(n=13)$ respondents answered 'yes.' Surprisingly, most of the nurses who experienced spiritual care training $69.3 \%$ $(n=9)$ felt still incapable of delivering spiritual care.

Table 3. Distribution of Mean Score of Spiritual Care (SC), Spirituality (S) and Sprituality and Spiritual Care (SSCRS) on Individual Characteristics $(n=273)$

\begin{tabular}{lccc}
\hline Characteristics & \multicolumn{3}{c}{ Mean } \\
& SC & S & SSCRS \\
\hline Gender & & & \\
Female & 19.93 & 46.01 & 65.94 \\
Male & 20.02 & 46.40 & 66.42 \\
Age Range & & & \\
21-29 Years Old & 19.94 & 45.56 & 65.49 \\
30-39 Years Old & 19.79 & 46.35 & 66.14 \\
40-49 Years Old & 20.68 & 46.93 & 67.61 \\
> 50 years old & 18.75 & 48.00 & 66.75 \\
Geographic Region & & & \\
Southern & 20.15 & 47.24 & 67.38 \\
Center & 19.78 & 45.22 & 65.00 \\
Northern & 19.90 & 45.66 & 65.56 \\
Work Experience &. &. &. \\
< 1 years & 19.38 & 47.00 & 66.38 \\
1-5 years & 19.93 & 44.90 & 64.83 \\
6-10 years & 20.04 & 46.47 & 66.51 \\
11-25 years & 20.02 & 46.57 & 66.59 \\
over 25 years & 20.38 & 47.38 & 67.75 \\
Qualification & & & \\
Diirect Care & 19.87 & 45.89 & 65.76 \\
Nurse Leader & 20.19 & 46.84 & 67.02 \\
Work Shift & & & \\
Days & 20.05 & 46.43 & 66.48 \\
Rotated & 19.94 & 46.10 & 66.04 \\
Working Time & & & \\
Full Time & 19.98 & 46.19 & 66.17 \\
\hline
\end{tabular}


Jurnal Keperawatan Soedirman 14 (2) 2019 : 103 - 113

\begin{tabular}{lccc}
\hline \hline \multirow{2}{*}{ Characteristics } & \multicolumn{3}{c}{ Mean } \\
& SC & S & SSCRS \\
\hline Part Time & 19.85 & 46.00 & 65.85 \\
Specialties &. &. &. \\
Med-Surgical & 19.81 & 45.45 & 65.25 \\
Maternity & 20.08 & 45.83 & 65.92 \\
Paediatric & 20.12 & 46.64 & 66.76 \\
Critical Emergency. & 19.96 & 46.75 & 66.71 \\
Community \& others & 21.00 & 49.23 & 70.23 \\
\hline
\end{tabular}

Table 4. Exposed to Concept of Spiritual Care $(\mathrm{N}=273)$

\begin{tabular}{lcc}
\hline Question & $\mathbf{n}$ & Percent \% \\
\hline $\begin{array}{l}\text { During the course of your } \\
\text { nurse training, did you } \\
\text { receive any }\end{array}$ & \\
lessons/lectures covering & & \\
Spiritual Care? & & \\
No & 44 & $16.1 \%$ \\
Not Remember & 86 & $31.5 \%$ \\
Yes & 143 & $52.4 \%$ \\
Since qualifying as a & & \\
nurse have you been on & & \\
any training courses which & & \\
covered Spiritual Care? & & \\
No & 260 & $95.2 \%$ \\
Yes & 13 & $4.8 \%$ \\
Feel incapable to deliver & 9 & $70 \%$ \\
Spiritual Care after & & \\
Training (N=13) & \\
\hline
\end{tabular}

\section{Experiencing Spiritual Care}

We also explored the

respondents' experience in delivering nursing care to respond patient spiritual need. We asked a question "Selama bekerja sebagai perawat, pernahkah Anda menjumpai pasien dengan kebutuhan spiritual/During nursing practice have you encounter patient with spiritual need?" Most of the respondent $90.1 \% \quad(n=246)$ encountered patients with spiritual need in clinical practice. For those, who encountered spiritual need were asked how they became aware patient had the need (Table 5). In this question, respondents could choose more than one answer, so that the calculation of percentage base on the total sample for each option. Listening and observing the patient $67.7 \% \quad(n=167)$ and patients themselves $38.5 \%(n=95)$ were the most common way that made them aware that the patient has a spiritual need. In contrast, NCP and other nurses were selected only by $5.5 \%(n=16)$ and $3.7 \%$ $(n=9)$ respondents respectively. The religious leader, the patient's family-andfriends was also selected as resources that made them aware the patients' spiritual need.

\section{Perception of Responsibility}

Similar to the question to identify what/who opened nurses awareness to the patients spiritual need, we provide options to be checked by respondents to answer the question "Siapa yang menurut Anda bertanggung jawab terhadap perawatan spiritual?/Who do you feel should be responsible for providing spiritual care?". Most of responded quite similarly by nearly checked the options provided. The selected options included nurses, chaplains, patient's family-andfriends, and the patient themselves. It seemed nurses understood that the spiritual care is under their responsibility too. However, chaplain or religious leader are the most selected by respondents.

Table 5. How Nurse Aware Patient's Spiritual Need and The Perception of Who Responsible in ( $N=273$ )

\begin{tabular}{|c|c|c|}
\hline $\begin{array}{l}\text { Multiple Options } \\
\text { Questioner }\end{array}$ & $\begin{array}{c}\text { Selected } \\
\text { by }\end{array}$ & $\begin{array}{l}\text { Percent } \\
\text { (\%) }\end{array}$ \\
\hline $\begin{array}{l}\text { How did you become } \\
\text { aware of patients' } \\
\text { spiritual need? }\end{array}$ & & \\
\hline $\begin{array}{l}\text { Chaplain/Religious } \\
\text { Leaders }\end{array}$ & 9 & $3.7 \%$ \\
\hline $\begin{array}{l}\text { Listening to and } \\
\text { observing the patient }\end{array}$ & 167 & $67.9 \%$ \\
\hline Nursing Care Plan & 16 & $6.5 \%$ \\
\hline Other Nurses & 9 & $3.7 \%$ \\
\hline Patient her/himself & 95 & $38.6 \%$ \\
\hline $\begin{array}{l}\text { Patient's } \\
\text { relatives/friends } \\
\text { Who do you feel should } \\
\text { be responsible for } \\
\text { providing Spiritual }\end{array}$ & 35 & $14.2 \%$ \\
\hline Chaplain/Clergy & 263 & $96.3 \%$ \\
\hline Nurses & 262 & $95.6 \%$ \\
\hline Patient themselves & 261 & $95.6 \%$ \\
\hline $\begin{array}{l}\text { Patients Family and } \\
\text { Friends }\end{array}$ & 251 & $91.9 \%$ \\
\hline $\begin{array}{l}\text { Patients own } \\
\text { spiritual/religious }\end{array}$ & 255 & $93.4 \%$ \\
\hline
\end{tabular}


Jurnal Keperawatan Soedirman 14 (2) 2019 : 103 - 113

\begin{tabular}{|c|c|c|c|}
\hline $\begin{array}{r}\text { Table 6. The } \\
\text { Cha } \\
\text { SSC }\end{array}$ & $\begin{array}{c}\text { Result } \\
\text { acteristics } \\
\text { 3S ( }=273) \\
\end{array}$ & of $\begin{array}{r}\text { Demog } \\
\text { Variation }\end{array}$ & $\begin{array}{r}\text { aphic } \\
\text { of }\end{array}$ \\
\hline Characteristics & $\begin{array}{c}\text { Spiritual } \\
\text { Care }\end{array}$ & Spirituality & $\begin{array}{c}\text { Total } \\
\text { SSCRS }\end{array}$ \\
\hline Gender (t test) & 0.707 & 0.464 & 0.478 \\
\hline $\begin{array}{l}\text { Geographical } \\
\text { Location }\end{array}$ & 0.438 & $0.002^{*}$ & $0.006^{*}$ \\
\hline Age Range & $\begin{array}{l}0.051 / 0 \\
048^{\star}(\mathrm{b})\end{array}$ & 0.232 & 0.223 \\
\hline $\begin{array}{l}\text { Work } \\
\text { Experience }\end{array}$ & 0.679 & $\begin{array}{c}0.064 / 0.041 \\
{ }^{*}(\mathrm{~b})\end{array}$ & 0.217 \\
\hline $\begin{array}{l}\text { Qualification } \\
\text { (t test) }\end{array}$ & 0.249 & 0.094 & 081 \\
\hline $\begin{array}{l}\text { Current Work } \\
\text { Specialties }\end{array}$ & 0.704 & 0.181 & 213 \\
\hline $\begin{array}{l}\text { Working Time } \\
\text { (t test) }\end{array}$ & 0.754 & 0.830 & 0.777 \\
\hline $\begin{array}{l}\text { Working Shift } \\
\text { (t test) }\end{array}$ & 0.706 & 0.604 & 0.587 \\
\hline
\end{tabular}

\section{The Variation of SSCRS Score on Demographic Characteristic \\ The association \\ each}

demographic characteristic to the score of SSCRS both wholly or based on each Spiritual Care and Spirituality scores were tested. Perception of respondents on Spiritual Care were not different significantly based on gender, geographic location, age, work experience, current job specialties, working time, and working shift. However, after adjusting the extreme value, there was a significant different of perception of spiritual care based on age $(p=0.48)$. The perception of spirituality also had a different result. Geographic location was the only variable that has a significant different of spirituality score $(p=0.002)$. However, after adjusting the extreme value, the spirituality scores also significant based on the geographic location ( $p: 0.002$ ). Geographic location had shown a different of total SSCRS as a whole score ( $p: 0.006)$.

\section{DISCUSSION}

Findings of this study indicated SSCRS average score $66.1( \pm 4.5)$, was better than compared studies in other countries. For example, a study among Turkey nurses reported the SSCRS score was $62.43( \pm 7.54)$ (Çetinkaya, Altundağ Dündar, \& Azak, 2013). So do the score among Iran nurses $63.40 \quad( \pm 4.57)$ (Mazaheri, Falahi, Sadat, \& Rahgozar,
2009). Iran and Turkey were countries where Islamic values colorizes their cultural lives. While, even though Islam was a majority, the cultural lives was varies in each region. Since the majority of sample in this study was affiliated to Islam too, the similarity among these three countries was comparable.

Another finding also indicated that nurses characteristic might not contribute to their perception of spirituality and spiritual care except demographic characteristic. Analysis results showed the $p$ values of each individual characteristics were higher than 0.5 except demographic factor $(0.006)$ (Table 6). This finding was different with a study among Hongkong Enrolled Nurses. This study reported the higher education level of nurses (degree compared to certificate and diploma nurses) the better their perception of spirituality and spiritual care. Also, nurses affiliated to religion perceive spirituality and spiritual care better than ones were not affiliated to religion (Wong, Lee, \& Lee, 2008).

While, the variation of SSCRS average score by geographic area showed uniqueness the finding of this study. Nurses in southern area of Central Java perceived spiritual care and spiritual care better than those who lived int the center and northern area by 20.15 and 47.24 respectively (Table 3 ).

Historically, Northern area of central java were more religious than other area. Because, Islam religion developed well on the northern side of Java Island. Life in the northern cities such as Demak, Pati, and Kudus, had been influenced by Islamic cultural and social life. In fact, the northern people were less sensitive to the need of spirituality.

Religious color was not guarantee the acceptability to the spiritual need. For example, in a study about nurse's organizational commitment, even though the hospital hold a strong religious background, most of nurses felt their spirituality were well-facilitated (Mulyono, 2011). In contrast, less religious tend to open to practicing the spiritual values. Therefore, citizen in Banyumas (a city in southern area) had different ways in 
perception of religion and spiritual as well as how they interpreted the values for daily living (Mufid, 2006).

\section{Changing of Spirituality}

One-way ANOVA showed a significant variation of mean, among respondents. The nurse worked between 1-5 years tended to have a lower score compared to another group. Different of motive and job satisfaction in work seemed rational to explain this finding. Job satisfaction and tenure in work made a $\mathrm{U}$ shape pattern. High in earlier, drop in age of twenty and increase again (Herzberg in Padmaja, Bhar, \& Gangwar, 2013).

In the early of work mostly new nurse will experience the exciting moment and reflect it into religious or spiritual value they hold. Most nurses in this group came from young Indonesian religious group (Sallquist, Eisenberg, French, Purwono, \& Suryanti, 2010). Following this, in the first five years of employment, they faced dynamic in work setting, unsatisfied with the work environment. Work situation criticizes their religious values and tends to be a rational person, because some person may question about God role and temporarily lost connection with the God (Penson in Agrimson \& Taft, 2009). However, their level of caring behavior (Sulistyanto, 2009) prevent them from avoiding meeting patient with spiritual transformation. Supported by better and stable job position, wide opportunity to face complex and traumatic event in a relationship with patient and other, turn back their belief and hope. In such of the crisis in finding meaning and purpose of their life, they surrender to the Supreme Being they previously believed. Thus, promote spiritual development. Finally, they got benefit from the experience and continue to find meaning and purpose of their job (Agrimson \& Taft, 2009; McBrien, 2006; Sallquist et al., 2010)

\section{Learning Spirituality is challenging}

Learning spirituality was reported very challenging by respondents. For example, only $52.4 \%$ (142) nurses remembered there were taught with spirituality concept during their education.
Moreover, even though 13 percent have been trained with the spiritual care issue in work setting, 7 of 13 remained felt incompetence in delivering spiritual care. This study was relevant with previous study that only $25.4 \%$ (15) nurses had a good spiritual competence (Arini, Susilowati, \& Mulyono, 2015). This finding confirmed the difficulty level of learning and teaching spiritual care or spirituality in the school and the clinic.

Authors provided a number of argumentations in explaining how to learn spirituality and spiritual care. One argued that inclusion in the nursing curriculum be beneficial out of its limitation. The student can learn that the concept can be learned and transferable. The student also can follow the real nurse role modeling from the teacher (Taylor, Testerman, \& Hart, 2014). On the other hand, other authors also reported positive benefit if providing spiritual care as separated course. Because it opened the opportunity to deliver the learning process in the various innovative strategies (Shih, Gau, Mao, Chen, \& Kao Lo, 2001). However, adding content, or credit time will burden undergraduate nursing curriculum. Alternatively, advanced technology, great e-learning offered an alternative method to provide a course of spirituality and spiritual care as a continuing education. In fact, the online learning was not effective for working nurses as the learner (Feng et al., 2013). So that, developing an innovative learning design is a challenge to overcome the situation.

\section{Nurses Performed Spiritual Care as a Caring Behavior but Undocumented}

This study also indicated that teaching spirituality and spiritual care already affected the practice setting, however they were not well documented. Nurses sensitiveness to patient spiritual need through listening to the patients' statements, observing the signal, or family reports (Table 4) represented nurses' caring behavior. A study to in Surakarta confirmed that nurses caring behaviors were fairly good (Sulistyanto, 2009). Regrettably, nurses did not document their care well in their NCP. Consequently, the 
were a communication gap as reported that respondent rarely considered the patients spiritual need from the NCP or other nurses (Table 4).

Nursing documentation might influence poor scores of SSCRS. A study reported that more than half nursing documents suffered from a lack of quality (Triyanto \& Kamaluddin, 2008; Yanti \& Warsito, 2013). This condition would be worse if the nurse thought that nursing documentation burdened their job. Because workload and limited guidelines were responsible for the lack of providing spiritual care (Rushton, 2014; Stranahan, 2001). Since then, the nurses perceived spiritual care negatively.

The nursing document is a valuable resource for clinical learning. Lack of information resulted in losing potential resources for further investigation. According to Benner (1982), to be an expert, nurses should pass every steps of professional development. Unavailability of learning resources paused the nurses to be expert. Consequently, a novice would not have a role model in provideng spiritual care.

The Spiritual Care Score was Low while Spirituality Score was High.

Nurses' SC score tended to low (mean 20.1), comparing to the theoretical SC's median score (21). Without supporting environment, the nurse might change the perception to spirituality and spiritual care even though already exposed to the concept. Because spirituality was not in the basic of human need that commonly learned in nursing education. Since the environment did not put spirituality as the main organization issue; there is no reason for the nurse to respond the spiritual issue among patient enthusiastically.

Religious based organization did not guarantee to put interest on spiritual care and make the spiritual care become undeliverable care. Spiritual need is not an attractive business matter. The previous study to assess nursing spirituality and their organizational commitment identified that the nurse spirituality was not well facilitated even though they worked in the religiously affiliated hospital (Mulyono,
2011). Without organization support, barriers become stronger. Even the postregistration nurses will feel difficult to provide spiritual care (Milligan, 2004). Therefore, the nurse perception of spiritual care is lower than the perception of spirituality.

In contrast to perception to SC represented in the score, the perception of spirituality was better. The S's mean score (46.18) was higher than the theoretical median (35.5). Since this study located in Java, the spiritual trait of Javanese (Wijayanti \& Nurwianti, 2010) were involved in developing good perception of spirituality. This value and belief contribute in developing a positive correlation to the score of spirituality (Ozbasaran et al., 2011). Moreover, since 2000 , the word 'spiritual' and 'spiritualties' have been extensively used in books, research publication, training, and other religious activities (Muttaqin, 2012). The combination of original spiritual belief and newly acquired concepts of spirituality may take part dynamically in developing nurse perception. As reported in Iran, the nurse perception in Iran, which mostly Muslim, emerged similar theme in defining spirituality with the western (Mahmoodishan, Alhani, Ahmadi, \& Kazemnejad, 2010).

\section{CONCLUSION}

Nurses perceptions of spirituality was better than other compared countries. All nurses were similar in perceiving spirituality and spiritual care; except those who lived in the southern area in Central Java. Most nurses had a similar perception of spirituality and spiritual care. Only geographic characteristic has significant variation. This study also confirmed challenges in teaching spirituality and spiritual care.

\section{LIMITATION}

The power sample of this study was higher than 0.9 however, Javanese population dominated the sample that possibly could change the results on the various population. Moreover Central Java province was only a small part of the bigger Indonesia. Wider coverage and 
more heterogeneous and representative sampling might refine the finding.

\section{ACKNOWLEDGEMENT}

We would like to say thanks to every individual who contributes in every step since preparing to write this manuscript. Thanks to DIKTI Scholarship Program from Ministry of Education Research and the Technology Republic Indonesia, Institute of Allied Health Sciences, College of Medicine, National Cheng Kung University, Prof. Wilfred McSherry for permitting us to use the SSCRS.

\section{REFERENCES}

Agrimson, L. B., \& Taft, L. B. (2009). Spiritual crisis: a concept analysis. Journal of Advanced Nursing, 65(2), 454-461. doi:10.1111/j.1365.2648.20 08.04869.x

Arini, H. N., Susilowati, I., \& Mulyono, W. A. (2015). Hubungan spiritualitas perawat dan kompetensi asuhan spiritual. 2015, 11. doi:http://dx.doi. org/10.20884/1.jks.2015.10.2.594

Balboni, T. A., Paulk, M. E., Balboni, M. J., Phelps, A. C., Loggers, E. T., Wright, A. A., . . Prigerson, H. G. (2010). Provision of spiritual care to patients with advanced cancer: associations with medical care and quality of life near death. Journal of Clinical Oncology, 28(3), 445-452. doi:10.12 00/JCO.2009.24.8005

Baldacchino, D. R. (2011). Teaching on spiritual care: the perceived impact on qualified nurses. Nurse Education in Practice, 11(1), 47-53. doi:10.1016/j.nepr.2010.06.008

Benner, P. (1982). From novice to expert... The dreyfus model of skill acquisition. American Journal of Nursing, 82, 402-407.

Boswell, C., Cannon, S. B., \& Miller, J. (2013). Students' perceptions of holistic nursing care. Nursing Education Perspectives, 34(5), 329333.
Çetinkaya, B., Altundağ Dündar, S., \& Azak, A. (2013). Nurses' perceptions of spirituality and spiritual care. Australian Journal of Advanced Nursing, 31(1), 5-10.

Daftar Anggota AIPNI. (2016). Retrieved from http://aipni-ainec.com/id/ang gota_list/

Feng, J.-Y., Chang, Y.-T., Chang, H.-Y., Erdley, W. S., Lin, C.-H., \& Chang, Y.-J. (2013). Systematic Review of Effectiveness of Situated E-Learning on Medical and Nursing Education. Worldviews on Evidence-Based Nursing, 10(3), 174-183 110p. doi:10.1111/wvn.12005

Mahmoodishan, G., Alhani, F., Ahmadi, F., \& Kazemnejad, A. (2010). Iranian nurses' perception of spirituality and spiritual care: a qualitative content analysis study. Journal of Medical Ethics \& History of Medicine, 3(1), 18.

Mazaheri, M., Falahi, K. M., Sadat, M. S., \& Rahgozar, M. (2009). Nursing attitude to spirituality and spiritual care.

McBrien, B. (2006). Spirituality: A concept analysis of spirituality. British Journal of Nursing, 15(1), 42-45.

McSherry, W., Draper, P., \& Kendrick, D. (2002). The construct validity of a rating scale designed to assess spirituality and spiritual care. International Journal of Nursing Studies, 39(7), 723-734. doi:10.1016/S0020-7489(02)00014-7

McSherry, W., \& Jamieson, S. (2011). An online survey of nurses' perceptions of spirituality and spiritual care. Journal of Clinical Nursing, 20(1112), 1757-1767. doi:10.1111/j.13652702.2010.03547.x

McSherry, W., \& Jamieson, S. (2013). The qualitative findings from an online survey investigating nurses' perceptions of spirituality and 
spiritual care. Journal of Clinical Nursing, 22(21-22), 3170-3182. doi:10.1111/jocn.12411

Milligan, S. (2004). Perceptions of spiritual care among nurses undertaking post registration education. International Journal of Palliative Nursing, 10(4), 162-171.

Mufid, A. S. (2006). Tangklukan, abangan, dan tarekat: Kebangkitan agama di Jawa (1 ed.). Jakarta: Yayasan Obor.

Mulyono, W. A. (2011). Penerapan spiritualitas di tempat kerja di RSIF dan hubungannya dengan kepuasan kerja perawat. Jurnal Keperawatan Soedirman, 6(2).

Muttaqin, A. (2012). Islam and the changing meaning of spiritualitas and spiritual in contemporary Indonesia. Al-Jami'ah: Journal of Islamic Studies, 50(1), 23-56.

Ozbasaran, F., Ergul, S., Temel, A. B., Aslan, G. G., \& Coban, A. (2011). Turkish nurses' perceptions of spirituality and spiritual care. Journal of Clinical Nursing, 20(21-22), 31023110. doi:10.1111/j.1365.2702.2011. 03778.x

Padmaja, K. V., Bhar, S., \& Gangwar, S. (2013). Work Experience, Motivation and Satisfaction--Do they go together? Journal of Institute of Public Enterprise, 36(3/4), 49-83.

Ruder, S. (2013). Spirituality in nursing: nurses' perceptions about providing spiritual care. Home Healthcare Nurse, 31(7), 356-367. doi:10.1097/ $\mathrm{NHH} .0 \mathrm{~b} 013 \mathrm{e} 3182976135$

Rushton, L. (2014). What are the barriers to spiritual care in a hospital setting? British Journal of Nursing, 23(7), 370-374.

Sallquist, J., Eisenberg, N., French, D. C., Purwono, U., \& Suryanti, T. A. (2010). Indonesian adolescents' spiritual and religious experiences and their longitudinal relations with socioemotional functioning.Develop mental Psychology, 46(3), 699-716. doi:10.1037/a0018879

Shih, F.-J., Gau, M.-L., Mao, H.-C., Chen, C.-H., \& Kao Lo, C.-H. (2001). Empirical validation of a teaching course on spiritual care in Taiwan. Journal of Advanced Nursing, 36(3), 333-346. doi:10.1046/j.1365.2648.20 01.01978.x

Stranahan, S. (2001). Spiritual perception, attitudes about spiritual care, and spiritual care practices among nurse practitioners. Western Journal of Nursing Research, 23(1), 90-104.

Sulistyanto, D. (2009). Hubungan antara persepsi pasien tentang perilaku caring perawat dengan kecemasan pasien kemoterapi pada kanker payudara di RSUD Dr. Moewardi Surakarta. (Thesis), Universitas Muhammadiyah Surakarta.

Taylor, E. J., Testerman, N., \& Hart, D. (2014). Teaching spiritual care to nursing students: An integrated model. Journal of Christian Nursing, 31(2), 94-99. doi:10.1097/CNJ.0000 000000000058

Timmins, F., \& Neill, F. (2013). Teaching nursing students about spiritual care -- A review of the literature. Nurse Education in Practice, 13(6), 499505. doi:10.1016/j.nepr.2013.01.011

Triyanto, E., \& Kamaluddin, R. (2008). Gambaran Motivasi Perawat Dalam Melakukan Dokumentasi Keperawat an Di Rsud Prof. Dr. Margono Soekarjo Purwokerto. 2008, 15.

Wijayanti, H., \& Nurwianti, F. (2010). Kekuatan karakter dan kebahagiaan pada suku jawa. Jurnal Psikologi, 3(2), 114-122.

Wong, K. F., Lee, L. Y. K., \& Lee, J. K. L. (2008). Hong Kong enrolled nurses' perceptions of spirituality and 
Jurnal Keperawatan Soedirman 14 (2) 2019 : 103 - 113

spiritual care. International Nursing Review, 55(3), 333-340. doi:10.11 11/j.1466-7657.2008.00619.x

Yanti, R. I., \& Warsito, B. E. (2013). Hubungan karakteristik perawat, motivasi, dan supervisi dengan kualitas dokumentasi proses asuhan keperawatan. Jurnal Manajemen Keperawatan, 1(2). 